\title{
Accelerated Cellular Uptake and Metabolism of L-Thyroxine during Acute Salmonella typhimurium Sepsis
}

\author{
Frederick R. DeRubertis and Kenneth A. Woeber \\ From the U. S. Army Medical Research Institute of Infectious Diseases, \\ Frederick, Maryland 21701
}

A в S T R A T The effects of acute Salmonella typhimurium sepsis on the kinetics of peripheral L-thyroxine ( $\left.\mathrm{T}_{4}\right)$ distribution and metabolism and on serum total and free $T_{4}$ concentrations were studied in rhesus monkeys inoculated i.v. with either heat-killed or viable organisms. The rate of disappearance of labeled $T_{4}$ from serum was increased within $8 \mathrm{~h}$ after inoculation of monkeys with either heat-killed or viable Salmonella. The effects of the heat-killed organisms were transient and no longer evident by $16 \mathrm{~h}$ postinoculation. The monkeys inoculated with the viable Salmonella experienced a 2-3 day febrile, septic illness that was accompanied by an increase in the absolute rate of $T_{4}$ disposal. In the infected monkeys, serum total $T_{4}$ and endogenously labeled protein-bound iodine concentrations fell significantly during the period of acute sepsis and then rose during convalescence to values that exceeded the preinoculation values, suggesting that thyroidal secretion of hormone had increased in response to a primary depletion of the peripheral hormonal pool. Total cellular and hepatic uptakes of $T_{4}$ were enhanced by $4 \mathrm{~h}$ after inoculation of monkeys with either heatkilled or viable Salmonella, but the increase in total cellular uptake persisted for $24 \mathrm{~h}$ only in the monkeys inoculated with the viable organisms. These alterations in $T_{4}$ kinetics could neither be correlated with changes in the binding of $T_{4}$ in plasma nor attributed to an increase in vascular permeability. Moreover, they could not be ascribed to an in vitro product of bacterial growth, suggesting that the presence of the organisms themselves was required. An acceleration of $T_{4}$ disappearance was also observed during Escherichia coli and Diplococcus pneumoniae bacteremias. Our findings are

Dr. Woeber's present address is the University of California Medical Service, San Francisco General Hospital, San Francisco, Calif. 94110.

Received for publication 5 June 1972 and in revised form 29 August 1972. consistent with a primary increase in the cellular uptake and metabolism of $T_{4}$ during bacterial sepsis, possibly related to phagocytic cell function in the host.

\section{INTRODUCTION}

Accelerated metabolism of the thyroid hormones has been observed during acute pneumococcal infections in man and the rhesus monkey $(1,2)$. In the monkey, cellular uptake of L-thyroxine $\left(T_{4}\right)^{1}$ is enhanced during the early course of this illness (3). Moreover, localization of both labeled $\mathrm{T}_{4}$ and $\mathrm{L}$-triiodothyronine in affected areas of lung has been reported to occur in patients with bacterial pulmonary infections (4). The pathogenesis and significance of these alterations in the distribution and metabolism of the thyroid hormones during infection are not clear. Studies with peripheral leukocytes in vitro suggest that these alterations might constitute a host defense mechanism in which phagocytozing cells utilize thyroid hormone as a source of iodine in a peroxidase-hydrogen peroxidehalide system for the iodination and killing of ingested microorganisms $(2,5-9)$. However, the extent to which iodide or the thyroid hormones participate in vivo in this putative antimicrobial system remains uncertain $(6,10,11)$.

An early study by Sterling and Chodos (12) revealed an increase in the absolute rate of $T_{4}$ disposal in five

\footnotetext{
${ }^{1}$ Abbreviations used in this paper: $\mathrm{AFT}_{4}$ absolute free $\mathrm{T}_{4}$ concentration; CONT, monkeys inoculated with isotonic saline; $\mathrm{CU}_{\mathrm{T}_{4}}$, cellular uptake of $\mathrm{T}_{4} ; \mathrm{D}_{\mathrm{T}_{4},}, \mathrm{~T}_{4}$ absolute disposal rate; $\% \mathrm{FT}_{4}$, percent of free $\mathrm{T}_{4} ;\left[{ }^{125} \mathrm{I}\right] \mathrm{Alb},{ }^{125} \mathrm{I}$-labeled albumin; INF, monkeys inoculated with saline suspension containing viable $S$. typhimurium; $\mathrm{K}_{\mathrm{T}}$, fractional rate of $\mathrm{T}_{4}$ disappearance; $\mathrm{MCR}_{\mathrm{T}}, \mathrm{T}_{4}$ metabolic clearance rate; $\mathrm{PB}$ ${ }^{125} \mathrm{I}$, protein-bound ${ }^{125} \mathrm{I}$; SALM, monkeys inoculated with saline suspension containing heat-killed $S$. typhimurium; $\mathrm{T}_{4}$, L-thyroxine; TCA, trichloroacetic acid; $\mathrm{V}_{\mathrm{T} 4}, \mathrm{~T}_{4}$ distribution volume.
} 
febrile patients, four of whom had leukemia and one, a urinary tract infection. More recent work has revealed only variable changes in thyroid hormone economy during systemic bacterial infections in man (13-16). However, in some of these studies, evaluation of the impact of the infection on thyroid hormone economy was made only at a single point in time late during the course of the illness (16) or did not include evaluation of the kinetics of peripheral hormonal metabolism (15, 16). Accordingly, the present study was undertaken to assess the effects of Salmonella typhimurium and Escherichia coli sepsis on several aspects of thyroid hormone economy in the rhesus monkey. The similarity in the responses of man and the rhesus monkey to pneumococcal infections suggested that this species would be an appropriate animal to examine the effects of other acute model infections.

\section{METHODS}

Healthy, male rhesus monkeys (Macaca mulatta) weighing between 2.5 and $4.3 \mathrm{~kg}$ were placed in primate chairs, fed a standard or iodine-deficient diet (2), and allowed water ad lib. Rectal temperatures, complete blood counts, and blood cultures were obtained frequently, as indicated in the results. In all experiments, the concentration of radioactivity in serum refers to protein-bound radioactivity, as determined by trichloroacetic acid (TCA) precipitation of $250 \mu \mathrm{l}$ of serum (2). Blood samples $(1 \mathrm{ml})$ were obtained by saphenous venipuncture; at those times when multiple determinations were to be made, larger volumes $(2-5 \mathrm{ml})$ were withdrawn.

Studics of the metabolic disappcarance of $T_{4}$. The metabolic disappearance of $T_{4}$ was studied during a 5 day period before and a 10 day period after i.v. inoculation of six monkeys with $1 \mathrm{ml}$ of isotonic saline (CONT) and five monkeys with $1 \mathrm{ml}$ of a saline suspension containing 1-3 $\times 10^{\circ}$ heat-killed (SALM) and 11 monkeys with viable (INF) Salmonella typhimurium. ${ }^{2}$ To label the peripheral hormonal pool for three successive studies, $10 \mu \mathrm{Ci}$ of ${ }^{131} \mathrm{I}-$ labeled $\mathrm{T}_{4}\left(\left[{ }^{131} \mathrm{I}\right] \mathrm{T}_{4}\right)^{3}$ were injected i.v. 5 days before, at the time of, and 5 days after inoculation ${ }^{4}$ of monkeys with either saline or the bacteria. When the $\left[{ }^{131} \mathrm{I}\right] \mathrm{T}_{4}$ was administered at the time of inoculation, it was injected first into one saphenous vein followed in 2-3 min by inoculation with the bacteria into the opposite saphenous vein. Follow-

${ }^{2}$ The Salmonella typhimurium employed in the present study was isolated from a natural infection in a rat by the Massachusetts Institute of Technology Nutritional Pathology Laboratory, Cambridge, Mass. The organisms were the generous gift of Dr. Paul M. Newberne, Department of Nutrition and Food Science, Massachusetts Institute of Technology, Cambridge, Mass. The organisms were monkey-passed several times prior to their use in the current studies, and were cultured on nutrient agar slants for 18 $\mathrm{h}$ and harvested by saline lavage just prior to inoculation. Killed bacteria were prepared by heating at $56^{\circ} \mathrm{C}$ for $1 \mathrm{~h}$.

${ }^{3}$ Obtained from Abbott Laboratories, Chemical Marketing Div., North Chicago, I11.

4 Throughout, inoculation refers to time of administration of saline, organisms, or biological products and injection to administration of labeled materials. ing each injection of labeled hormone, the declining concentration of radioactivity in serum during the subsequent 5 day period was plotted against time. In 14 of these monkeys made iodine deficient by diet, $25 \mu \mathrm{Ci}$ of carrier-free inorganic ${ }^{125} \mathrm{I}$ (footnote 5) was injected i.v. 15 days prior to inoculation to label the intrathyroidal iodine pool, and the concentration of endogenously labeled hormone (proteinbound ${ }^{125} \mathrm{I}, \mathrm{PB}{ }^{125} \mathrm{I}$ ) in serum was measured daily thereafter, as previously described (2). Postinoculation PB ${ }^{12 .} \mathrm{I}$ values in each monkey were expressed as a percent of the mean value for the daily $\mathrm{PB}{ }^{125} \mathrm{I}$ concentrations obtained during the 5 days prior to inoculation. To the remaining eight monkeys, $10 \mu \mathrm{Ci}$ of ${ }^{125} \mathrm{I}$-labeled human serum albumin $\left.\left({ }^{125} \mathrm{I}\right] \mathrm{Alb}\right)^{3}$ were administered simultaneously with the second injection of $\left[{ }^{131} \mathrm{I}\right] \mathrm{T}_{4}$ and its disappearance from serum followed during the postinoculation period.

For the first $48 \mathrm{~h}$ postinoculation, blood samples were obtained at 8 -h intervals in all 22 monkeys; in 16 monkeys, samples were also obtained at $1,2,4,6$, and $8 \mathrm{~h}$ postinoculation. During all other periods, blood samples were obtained daily. In accordance with previous observations in the rhesus monkey (2), apparent distribution equilibrium of residual [ $\left.{ }^{131} \mathrm{I}\right] \mathrm{T}_{4}$ was attained by $16 \mathrm{~h}$ after its i.v. injection. From 16 or 24 to $120 \mathrm{~h}$ the disappearance of labeled hormone from serum appeared to conform to a single exponential function of time in CONT and SALM, and was used to calculate the fractional rate of $T_{4}$ disappearance $\left(\mathrm{K}_{\mathrm{T}_{4}}\right)^{\circ}$. In INF, however, slowing of the disappearance curve was noted between 48 and $72 \mathrm{~h}$ postinoculation, the time during which bacteremia subsided in most monkeys. Accordingly, in INF, $K_{T_{4}}$ was calculated separately for the periods from 16 to $48 \mathrm{~h}$ (acute sepsis) and from 72 to $120 \mathrm{~h}$ (early recovery). For each time period, mean best-fit regression curves were calculated by the method of least squares; linearity of these curves and differences between their slopes were assessed statistically by the $t$ test (17). The rate of disappearance of $\left[{ }^{[25} \mathrm{I}\right] \mathrm{Alb}$ from serum was analyzed in a similar manner.

$T_{4}$ distribution volumes $\left(V_{T_{4}}\right)$, metabolic clearance rates $\left(\mathrm{MCR}_{\mathrm{T}_{4}}\right)$, and absolute disposal rates $\left(\mathrm{D}_{\mathrm{T}_{4}}\right)$ were calculated from data obtained after distribution equilibrium of residual $\left[{ }^{131} \mathrm{I}\right] \mathrm{T}_{4}$ had been attained, as previously described (2). Correction was always made for the concentration of radioactivity remaining in the peripheral hormonal pool (serum concentration $\times \mathrm{V}_{\mathbf{T}_{4}}$ ) from a previous injection of [ ${ }^{131} \mathrm{I} \mathrm{T}_{4}$; this value did not exceed $12 \%$ of the fresh dose of $\left[{ }^{131} \mathrm{I}\right] \mathrm{T}_{4}$ and was added to the latter in calculating $\mathrm{V}_{\mathrm{T}_{4}}$ by zero time extrapolation of the new disappearance curve. The mean value for serum total $T_{4}$ concentration during each period was employed to calculate the $D_{T_{4}}$ for that period. Complete urine and stool collections could not be obtained to correct for metabolism of injected $\left[{ }^{131} \mathrm{I}\right] \mathrm{T}_{4}$ prior to attainment of distribution equilibrium. Accordingly, to estimate the extent of early metabolism, the percent of non-TCA precipitable ${ }^{181} \mathrm{I}$ in serum was measured in three CONT, three SALM, and three INF during the first $8 \mathrm{~h}$ after inoculation, and thyroidal ${ }^{131} \mathrm{I}$ uptake was measured in three additional monkeys (one CONT, one SALM, and one INF) that were killed $8 \mathrm{~h}$ after inoculation by injecting intravenously a highly concentrated pentobarbital solution. ${ }^{7}$

\footnotetext{
${ }^{5}$ Obtained from New England Nuclear Corp., Boston, Mass.

${ }^{6}$ Throughout, $\mathrm{K}_{\mathrm{T}_{4}}$ refers to fractional rate of $\mathrm{T}_{4}$ disappearance after attainment of distribution equilibrium of residual $\left[{ }^{131} \mathrm{I}\right] \mathrm{T}_{4}$.

${ }^{7}$ Lethane obtained from A. J. Buck \& Co., Baltimore, Md.
} 
Serum total $T_{4}$ concentration and the percent of free $T_{4}$ $\left(\% \mathrm{FT}_{4}\right)$ were measured prior to and at $8,24,48,96$, and $192 \mathrm{~h}$ after inoculation with saline or bacteria, employing methods previously described (3). The basal values shown represent the mean of the two determinations made at 5 days and immediately prior to inoculation. Serum absolute free $\mathrm{T}_{4}$ concentration $\left(\mathrm{AFT}_{4}\right)$ was calculated as the product of serum total $\mathrm{T}_{4}$ concentration and $\% \mathrm{FT}_{4}$.

Studies of the distributive disappearance of $T_{4}$. In 21 additional monkeys, the distributive disappearance of $T_{4}$ was studied at 4, 14, 24, and $72 \mathrm{~h}$ after inoculation of monkeys with saline or with viable or heat-killed $S$. typhimurium. The cellular uptake of $\mathrm{T}_{4}\left(\mathrm{CU}_{\mathrm{T}_{4}}\right)$ was calculated from the differences in the instantaneous distribution volumes of $\left[{ }^{131} \mathrm{I}\right] \mathrm{T}_{4}$ and $\left[{ }^{125} \mathrm{I}\right] \mathrm{Alb}$ during a $60 \mathrm{~min}$ period following their simultaneous i.v. injection, as previously described $(3,18)$. At this time, the monkeys were killed by injecting intravenously a highly concentrated pentobarbital solution, ${ }^{7}$ and the liver, both kidneys, and the thyroid gland were removed. Net hepatic, renal, and thyroidal uptakes of ${ }^{131} \mathrm{I}$ at $60 \mathrm{~min}$ and hepatic and renal $\mathrm{T}_{4}$ spaces were determined, according to methods previously described in detail (3). To estimate the extent of degradation of $\left[{ }^{131} \mathrm{I}\right] \mathrm{T}_{4}$ during the $60 \mathrm{~min}$ following its injection, urinary excretion of ${ }^{131} \mathrm{I}$ was monitored. Complete, short-term urine collections were possible without instrumentation of the urinary tract by employing an adhesive pediatric bag $;^{8}$ residual bladder urine was obtained by aspiration at the time of sacrifice. The percent of non-TCA precipitable ${ }^{131} \mathrm{I}$ in serum was also monitored. $\% \mathrm{FT}_{4}$ in serum was measured in all monkeys immediately prior to inoculation with saline or bacteria and again at $60 \mathrm{~min}$ after injection of the labeled materials.

In 31 other monkeys, the rate of disappearance of $\left[{ }^{131} \mathrm{I}\right] \mathrm{T}$ from serum was also determined during the $8 \mathrm{~h}$ period following the i.v. inoculation of: A, six monkeys with saline; $\mathrm{B}$, three with $10^{\circ}$ heat-killed Diplococcus pneumoniae (Type I-A); C, three with $10^{\circ}$ viable $D$. pneumoniae ${ }^{*} \mathrm{D}$, three with $10^{9}$ heat-killed Escherichia coli; ${ }^{10} \mathrm{E}$, three with $10^{9}$ viable E. coli $;{ }^{10} \mathrm{~F}$, three with $15 \mu \mathrm{g}$ and 4 with $1500 \mu \mathrm{g}$ of endotoxin derived from $S$. typhimurium; ${ }^{11} \mathrm{G}$, three with a Millipore filtrate of the supernate from the usual inoculum of unwashed $S$. typhimurium; and $\mathrm{H}$, three with $10^{\circ}$ washed $S$. typhimurium. In groups $\mathrm{A}, \mathrm{B}, \mathrm{C}, \mathrm{D}$, and $\mathrm{E}$ observations of $\mathrm{T}_{4}$ disappearance were also made at 8 -h intervals for $48 \mathrm{~h}$ postinoculation.

Statistical analyses of the data were performed according to methods described by Snedecor and Cochran (17).

\section{RESULTS}

Studies of the metabolic disappearance of $T_{4}$. Fig. 1 depicts the mean temperature curves, mean neutrophil counts, and the mean best-fit regression curves for the disappearance from serum of $\left[{ }^{131} \mathrm{I}\right] \mathrm{T}_{4}$ during the 15 day period of study in the six monkeys inoculated with saline (CONT) and the five inoculated with $10^{\circ}$ heatkilled (SALM) and the 11 with $10^{\circ}$ viable (INF) $S$. typhimurium. During the 5 day basal period of observa-

\footnotetext{
${ }^{8}$ Obtained from Sterilon Corp., Buffalo, N. Y.

${ }^{\circ}$ Inoculum prepared as previously described (3).

${ }^{10}$ Organisms cultured, harvested, and killed in a manner identical to that described for S. typhimurium.

${ }^{11}$ Lipopolysaccharide B, S. typhimurium; obtained from Difco Laboratories, Detroit, Mich.
}

tion, rectal temperatures were similar in all groups and the total leukocyte counts were normal, with usually a relative lymphocytosis as has been previously noted (2).

After inoculation, rectal temperatures were slightly elevated at $8 \mathrm{~h}$ in CONT and SALM, perhaps due to the frequent manipulation of the monkeys. Leukocytosis of variable magnitude $(11,800-18,300)$ with a consistent increase in the proportion of neutrophils $(>70 \%)$ was noted at $8 \mathrm{~h}$ in SALM but not CONT; by $24 \mathrm{~h}$ the neutrophil count had returned toward the basal value. No other adverse effects were observed.

The monkeys inoculated with the viable $S$. typhimurium (INF) usually experienced a $2-3$ day febrile, septic illness followed by spontaneous recovery. Fever was evident in most monkeys by $8 \mathrm{~h}\left(103.4 \pm 0.4^{\circ} \mathrm{F}\right.$, mean $\pm \mathrm{SE}$ ). Total leukocyte and differential counts at that time in INF were comparable to those in SALM. Maximum temperature elevations (range 103.8-106.4 $\mathrm{F}$ ) and leukocytosis $(10,300-23,200$, with a preponderance of neutrophils) occurred at approximately $24 \mathrm{~h}$; leukopenia was not observed. Lethargy, diminished food intake, poor muscle tone, and mild hyperventilation were often noted during the acute illness. Watery diarrhea associated with stool cultures that grew $S$. typhimurium occurred in two monkeys. In two monkeys, $S$. typhimurium was cultured from blood at $72 \mathrm{~h}$, even though these animals showed other signs of improvement (decreasing temperature and leukocytosis) and eventually recovered spontaneously. Monkey 22, whose data is depicted separately in Fig. 1, experienced an atypical, prolonged (9 day) septic illness followed by spontaneous recovery. The infection was fatal in only 1 of the 11 monkeys.

Table I presents the values (mean $\pm \mathrm{SE}$ ) for $\mathrm{K}_{\mathrm{T}_{4}}, \mathrm{~V}_{\mathrm{T}_{4}}$, $M C R_{4}$, and $D_{T_{4}}$ in the three groups. Basal values for these parameters were similar in the three groups. Moreover, in CONT these parameters remained stable when assessed sequentially over the three consecutive 5 day periods. During the first $8 \mathrm{~h}$ postinoculation, the rate of disappearance of $\left[{ }^{131} \mathrm{I}\right] \mathrm{T}_{4}$ from serum in both SALM $(19.4 \pm 1.8 \% / \mathrm{h})$ and INF $(18.2 \pm 1.3)$ was accelerated compared with that of CONT $(6.8 \pm 0.6), P$ $<0.001$. By $8 \mathrm{~h}$, the percent of non-TCA precipitable ${ }^{131} \mathrm{I}$ in serum in SALM and INF was approximately twice that of CONT. In three additional monkeys sacrificed at $8 \mathrm{~h}$, an increase in thyroidal ${ }^{131}$ I uptake was noted in SALM (3.5\% dose) and INF (2.6) as compared with CONT (0.6).

In SALM, $\mathrm{K}_{\mathrm{T}_{4}}$ from 16 to $120 \mathrm{~h}(28.5 \pm 3.2 \% /$ day $)$ did not differ significantly from that of CONT or the basal value for this group. The calculated postinoculation $V_{T_{4}}$ was increased in SALM $(817 \pm 95 \mathrm{ml})$, with consequent increases in the calculated values for $M_{C R}$ and $\mathrm{D}_{\mathrm{r}_{4}}$. However, owing to the accelerated metabolism 

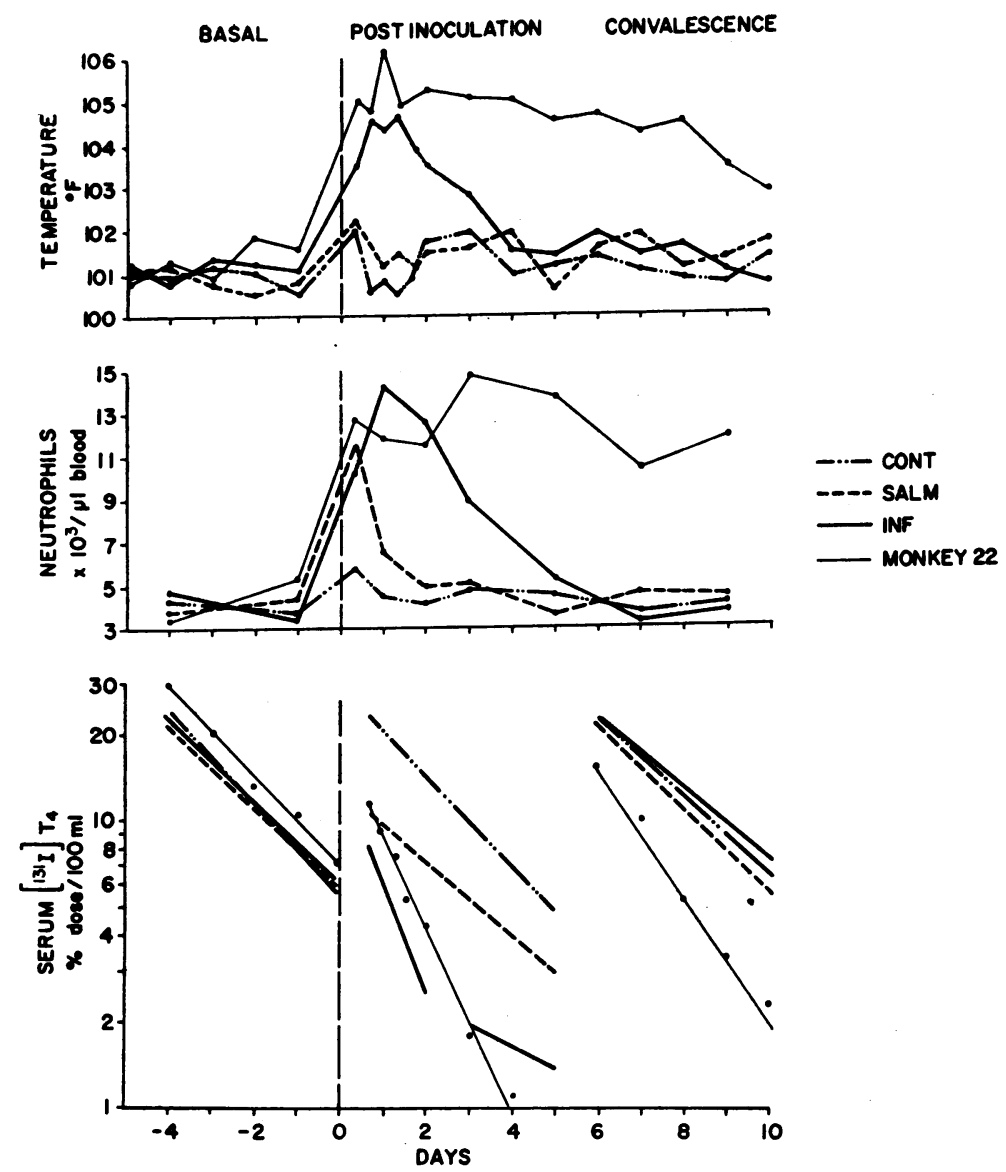

Figure 1 Mean temperatures curves, mean neutrophil counts, and mean best-fit regression curves for the disappearance from serum of ${ }^{131} I$-labeled $L$-thyroxine ([ $\left.\left.{ }^{131} I\right] T_{4}\right)$ during a 5 day period before and a 10 day period after i.v. inoculation, on day 0 , of six rhesus monkeys with saline (CONT) and five with $10^{\circ}$ heat-killed (SALM) and 11 with $10^{\circ}$ viable (INF) $S$. typhimurium. I.v. injections of $10 \mu \mathrm{Ci}$ of $\left[{ }^{121} \mathrm{I}\right] \mathrm{T}_{4}$ were given on days $-5,0$, and 5 . Linearity of the regression curves was confirmed statistically, $P$ at least $<0.05$. Temperature curve, neutrophil counts, and regression curves of monkey 22, which experienced a prolonged septic illness, are shown separately.

of $T_{4}$ prior to attainment of distribution equilibrium, the increase in calculated $V_{T_{4}}$ was exaggerated. When $M C R_{T_{4}}$ and $D_{T_{4}}$ were recalculated using the basal values of $\mathrm{V}_{\mathbf{T}_{4}}$ in this group, the values did not differ significantly from those of CONT. During convalescence, the values for the kinetic parameters were similar to those during the basal period.

In INF, $\mathrm{K}_{\mathbf{T}_{4}}$ during acute sepsis $(85.3 \pm 7.1 \%$ /day) differed significantly from that of CONT and the basal value for this group, $P<0.001$. Calculated values for $\mathrm{V}_{\mathrm{T}_{4}}(704 \pm 74 \mathrm{ml})$ and, às a result, $\mathrm{MCR}_{\mathrm{T}_{4}}$ and $\mathrm{D}_{\mathrm{T}_{4}}$ were increased, but to an exaggerated extent owing to the accelerated early degradation of hormone. Nevertheless, when $M C R_{T_{4}}$ and $D_{T_{4}}$ were recalculated using the basal values of $V_{r_{4}}$ in this group, the values $\left(M R_{r_{4}}, 269 \pm 31\right.$ $\mathrm{ml} /$ day; $\mathrm{D}_{\mathbf{T}_{4}}, \quad 16.5 \pm 1.8 \mu \mathrm{g} /$ day $)$ were significantly greater than those for CONT and the basal values for this group, $P<0.001$. In 9 of the 10 surviving INF, $\mathrm{K}_{\mathrm{T}_{4}}(20.4 \pm 2.7 \% /$ day $)$ was decreased between 72 and $120 \mathrm{~h}$ postinoculation (early recovery period) relative to the basal value. However, since the concentration of $\left[{ }^{131} \mathrm{I}\right] \mathrm{T}_{4}$ in serum was very low by $72 \mathrm{~h}$, and since $\mathrm{K}_{\mathrm{T}_{4}}$ might have been influenced by recycled $\left[{ }^{131} \mathrm{I}\right] \mathrm{T}$, or by accumulation of iodoprotein products of $\mathrm{T}_{4}$ metabolism, no attempt was made to calculate kinetic parameters for this period. Following a fresh injection of $\left[{ }^{181} \mathrm{I}\right] \mathrm{T}_{4}$ at $120 \mathrm{hr}$ (convalescent period), $\mathrm{K}_{\mathrm{T}_{4}}$ was still decreased in these monkeys $(29.4 \pm 2.0 \% /$ day $)$ compared with their own basal $\mathrm{K}_{\mathrm{T}_{4}}, P<0.02$, but $\mathrm{D}_{\mathrm{T}_{4}}$ was increased slightly relative to the basal value, owing to an increase in serum total $T$, concentration. In monkey 22 with pro- 
TABLE I

Sequential Changes in Peripheral L-Thyroxine $\left(T_{4}\right)$ Metabolism in Rhesus Monkeys Inoculated with Salmonella typhimurium

\begin{tabular}{|c|c|c|c|c|c|c|c|c|}
\hline Group & No. & & Period & $\mathrm{K}_{\mathrm{T}_{4}}$ & $\mathrm{~V}_{\mathrm{T}}$ & $\mathrm{MCR}_{\mathrm{T}_{4}}$ & $\begin{array}{l}\text { Serum } \\
\text { total } T_{4}\end{array}$ & $\mathrm{D}_{\mathrm{T}}$ \\
\hline & & & & $\% / d a y$ & $m l$ & $m l / d a y$ & $\mu \mathrm{g} / 100 \mathrm{ml}$ & $\mu g / d a y$ \\
\hline CONT & 6 & $\begin{array}{r}\text { I } \\
\text { II } \\
\text { III }\end{array}$ & $\begin{array}{l}\text { Basal } \\
\text { Postinoculation } \\
\text { Convalescence }\end{array}$ & $\begin{array}{l}37.4 \pm 1.4 \\
36.1 \pm 1.1 \\
32.0 \pm 2.3\end{array}$ & $\begin{array}{l}289 \pm 22 \\
342 \pm 12 \\
330 \pm 17\end{array}$ & $\begin{array}{l}107 \pm 6 \\
124 \pm 6 \\
105 \pm 8\end{array}$ & $\begin{array}{l}7.2 \pm 0.3 \\
6.9 \pm 0.2 \\
6.5 \pm 0.5\end{array}$ & $\begin{array}{l}7.8 \pm 0.8 \\
8.6 \pm 0.7 \\
6.7 \pm 0.7\end{array}$ \\
\hline SALM & 5 & $\begin{array}{r}\text { I } \\
\text { II } \\
\text { III }\end{array}$ & $\begin{array}{l}\text { Basal } \\
\text { Postinoculation } \\
\text { Convalescence }\end{array}$ & $\begin{array}{l}34.2 \pm 2.5 \\
28.5 \pm 3.2 \\
34.0 \pm 2.5\end{array}$ & $\begin{array}{c}333 \pm 28 \\
(817 \pm 95) \\
351 \pm 18\end{array}$ & $\begin{array}{c}111 \pm 6 \\
(221 \pm 8) \\
120 \pm 13\end{array}$ & $\begin{array}{l}6.9 \pm 0.8 \\
6.9 \pm 0.4 \\
7.2 \pm 0.5\end{array}$ & $\begin{array}{r}7.8 \pm 1.1 \\
(15.3 \pm 1.1) \\
8.4 \pm 0.7\end{array}$ \\
\hline INF & $\begin{array}{c}11 \\
11 \\
9 \ddagger \\
9 \ddagger\end{array}$ & $\begin{array}{l}\text { I } \\
\text { IIA } \\
\text { IIB } \\
\text { III }\end{array}$ & $\begin{array}{l}\text { Basal } \\
\text { Acute sepsis } \\
\text { Early recovery } \\
\text { Convalescence }\end{array}$ & $\begin{array}{l}35.8 \pm 1.4 \\
85.3 \pm 7.1^{*} \\
20.4 \pm 2.7 \\
29.4 \pm 2.0 \S\end{array}$ & $\begin{array}{c}313 \pm 16 \\
(704 \pm 74) \\
- \\
332 \pm 16\end{array}$ & $\begin{array}{c}111 \pm 7 \\
(570 \pm 51) \\
\overline{100 \pm 7}\end{array}$ & $\begin{array}{l}7.0 \pm 0.4 \\
6.2 \pm 0.4 \\
\overline{9} \\
9.4 \pm 0.8\end{array}$ & $\begin{array}{c}7.7 \pm 0.7 \\
(35.0 \pm 3.8) \\
\overline{-} \\
9.4 \pm 0.9\end{array}$ \\
\hline
\end{tabular}

CONT, inoculated with saline; SALM, inoculated with $10^{\circ}$ heat-killed S. typhimurium; and INF, inoculated with $10^{\circ}$ viable $S$. typhimurium. $\mathrm{K}_{\mathrm{T}_{4}}$, fractional disappearance rate; $\mathrm{V}_{\mathrm{T}_{4}}$, distribution volume; $\mathrm{MCR}_{\mathrm{T}_{4}}$, metabolic clearance rate; and $\mathrm{D}_{\mathrm{T}_{4}}$, absolute disposal rate. Mean values $\pm S E$ are shown. In SALM and INF, values for $V_{T_{4}}$ during period II, shown in parentheses with corresponding $\mathrm{MCR}_{\mathrm{T}_{4}}$ and $\mathrm{D}_{\mathrm{T}_{4}}$, were increased to an exaggerated extent owing to accelerated early degradation of $\mathrm{T}_{4}$; see text for details.

${ }^{*} P<0.001$ compared with corresponding basal value.

$\ddagger$ Excludes the one monkey that died at $51 \mathrm{~h}$ and the monkey with prolonged sepsis (monkey 22).

$\S P<0.02$ compared with corresponding basal value.

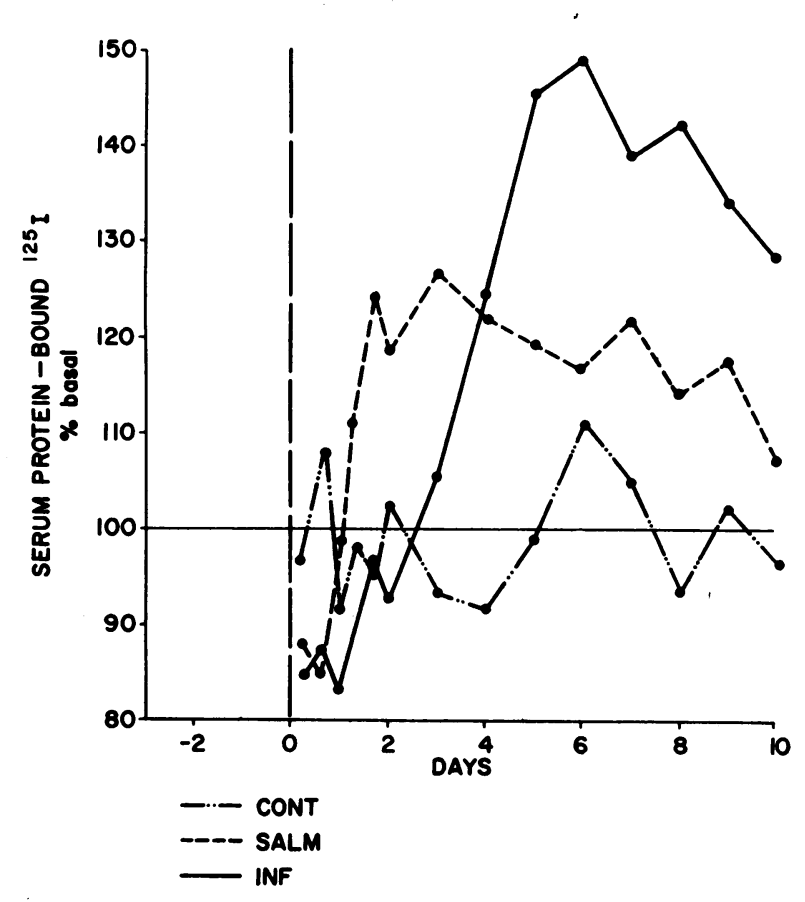

FIGURE 2 Sequential changes in the mean concentrations of endogenously labeled protein-bound ${ }^{125} \mathrm{I}\left(\mathrm{PB}{ }^{125} \mathrm{I}\right)$ in serum following i.v. inoculation, on day 0 , of four rhesus monkeys with saline (CONT) and three with $10^{\circ}$ heat-killed (SALM) and seven with $10^{\circ}$ viable (INF) S. typhimurium. The intrathyroidal iodine pool had been labeled with inorganic ${ }^{125} \mathrm{I} 15$ days prior to inoculation. Daily postinoculation values for $\mathrm{PB}{ }^{125} \mathrm{I}$ in each monkey were expressed as a percentage of the mean of the daily values obtained during the 5 day period preceding inoculation. longed sepsis, $\mathrm{K}_{\mathrm{T}_{\mathbf{4}}}$ remained accelerated throughout the illness (Fig. 1).

In contrast to the foregoing alterations in $T_{4}$ disappearance, the rate of disappearance of $\left[{ }^{125} \mathrm{I}\right] \mathrm{Alb}$ from serum did not differ among the three groups. During the first $8 \mathrm{~h}$ postinoculation, the values, expressed as percent per hour, were 4.1 and 3.9 in two CONT, 4.6 and 4.3 in two SALM, and $4.1 \pm 0.5$ in four INF. From 16 to $120 \mathrm{~h}$, the values, expressed as percent per day, were 16.7 and $16.0,18.2$ and 14.3 , and $16.6 \pm 2.1$, respectively.

Table II presents the sequential changes in serum total $\mathrm{T}_{4}, \% \mathrm{FT}_{4}$, and absolute free thyroxine $\left(\mathrm{AFT}_{4}\right)$. No significant alterations in these parameters were noted in CONT or SALM. By contrast, in INF by 48 $h$ postinoculation, serum total $T_{4}$ had fallen (5.0 \pm 0.4 $\mu \mathrm{g} / 100 \mathrm{ml}$ ) significantly compared with the basal value of this group $(7.0 \pm 0.4), P<0.01$, and $\% \mathrm{FT}$, had increased $(0.035 \pm 0.004)$ compared with the basal value $(0.026 \pm 0.001), P<0.05$. Mean $\% \mathrm{FT}_{4}$ in INF otherwise did not differ significantly from basal values, but serum total $\mathrm{T}_{4}$ had increased significantly by $192 \mathrm{hr}$ $(9.1 \pm 0.8), P<0.05$. No significant changes were noted in AFT. As depicted in Fig. 2, in seven of INF whose intrathyroidal iodine pools had been labeled with inorganic ${ }^{125} \mathrm{I}$, changes in serum $\mathrm{PB}{ }^{125} \mathrm{I}$, expressed as a percent of the mean basal value, followed a pattern qualitatively similar to that of serum total $\mathrm{T}_{4}$, with an initial fall (nadir, $83 \%$ at $24 \mathrm{~h} ; P<0.05$ ) and subsequent rise (peak, $149 \%$ at $144 \mathrm{~h} ; P<0.01$ ). A decrease in serum $\mathrm{PB}{ }^{125} \mathrm{I}$ (nadir, $84 \%$ at $16 \mathrm{~h}$ ) followed 
TABLE II

Sequential Changes in Serum Total L-Thyroxine $\left(T_{4}\right)$, Percent Free $T_{4}\left(\%_{4} F T_{4}\right)$, and Absolute Free $T_{4}$ Concentration (AFT ) in Rhesus Monkeys Inoculated with Salmonella typhimurium

\begin{tabular}{|c|c|c|c|c|c|c|}
\hline & \multirow[b]{2}{*}{ Basal } & \multicolumn{5}{|c|}{ Hours postinoculation } \\
\hline & & 8 & 24 & 48 & 96 & 192 \\
\hline \multicolumn{7}{|l|}{ CONT (6) } \\
\hline$T_{4}(\mu g / 100 \mathrm{ml})$ & $\begin{array}{l}7.2 \pm 0.3 \\
(6.0-8.5)\end{array}$ & $\begin{array}{c}7.5 \pm 0.6 \\
(5.5-10.0)\end{array}$ & $\begin{array}{l}6.7 \pm 0.3 \\
(6.0-8.0)\end{array}$ & $\begin{array}{l}6.8 \pm 0.5 \\
(4.5-9.0)\end{array}$ & $\begin{array}{l}6.3 \pm 0.7 \\
(4.5-9.0)\end{array}$ & $\begin{array}{l}6.5 \pm 0.4 \\
(50-7.5)\end{array}$ \\
\hline$\% \mathrm{FT}$ & $\begin{array}{l}0.025 \pm 0.002 \\
(0.018-0.029)\end{array}$ & $\begin{array}{l}0.024 \pm 0.002 \\
(0.019-0.031)\end{array}$ & $\begin{array}{l}0.025 \pm 0.003 \\
(0.019-0.033)\end{array}$ & $\begin{array}{l}0.026 \pm 0.002 \\
(0.020-0.030)\end{array}$ & $\begin{array}{c}0.024 \pm 0.002 \\
(0.022-0.034)\end{array}$ & $\begin{array}{c}0.022 \pm 0.002 \\
(0.017-0.028)\end{array}$ \\
\hline $\mathrm{AFT}_{4}(n g / 100 \mathrm{ml})$ & $\begin{array}{l}1.8 \pm 0.2 \\
(1.1-2.5)\end{array}$ & $\begin{array}{l}1.8 \pm 0.2 \\
(1.1-2.4)\end{array}$ & $\begin{array}{l}1.7 \pm 0.2 \\
(1.3-2.5)\end{array}$ & $\begin{array}{l}1.8 \pm 0.1 \\
(1.3-2.2)\end{array}$ & $\begin{array}{l}1.6 \pm 0.2 \\
(1.0-2.2)\end{array}$ & $\begin{array}{l}1.4 \pm 0.1 \\
(1.2-1.8)\end{array}$ \\
\hline \multicolumn{7}{|l|}{ SALM (5) } \\
\hline$T_{4}$ & $\begin{array}{l}6.9 \pm 0.8 \\
(3.5-8.0)\end{array}$ & $\begin{array}{l}6.1 \pm 0.7 \\
(3.5-7.0)\end{array}$ & $\begin{array}{l}6.4 \pm 0.4 \\
(5.5-7.5)\end{array}$ & $\begin{array}{l}7.4 \pm 0.7 \\
(5.5-9.0)\end{array}$ & $\begin{array}{l}7.7 \pm 0.7 \\
(6.0-9.5)\end{array}$ & $\begin{array}{r}7.2 \pm 0.5 \\
(6.0-9.0)\end{array}$ \\
\hline$\% \mathrm{FT}_{4}$ & $\begin{array}{c}0.026 \pm 0.002 \\
(0.021-0.029)\end{array}$ & $\begin{array}{l}0.024 \pm 0.001 \\
(0.020-0.029)\end{array}$ & $\begin{array}{l}0.026 \pm 0.002 \\
(0.023-0.032)\end{array}$ & $\begin{array}{l}0.026 \pm 0.002 \\
(0.020-0.030)\end{array}$ & $\begin{array}{l}0.025 \pm 0.002 \\
(0.020-0.031)\end{array}$ & $\begin{array}{l}0.024 \pm 0.003 \\
(0.020-0.035)\end{array}$ \\
\hline AFT & $\begin{array}{l}1.8 \pm 0.2 \\
(1.0-2.2)\end{array}$ & $\begin{array}{l}1.5 \pm 0.2 \\
(0.8-1.7)\end{array}$ & $\begin{array}{l}1.6 \pm 0.2 \\
(1.2-2.0)\end{array}$ & $\begin{array}{l}1.9 \pm 0.2 \\
(1.4-2.3)\end{array}$ & $\begin{array}{l}1.9 \pm 0.2 \\
(1.5-2.4)\end{array}$ & $\begin{array}{l}1.9 \pm 0.3 \\
(1.5-3.1)\end{array}$ \\
\hline \multicolumn{7}{|l|}{ INF (11) } \\
\hline$T_{4}$ & $\begin{array}{r}7.0 \pm 0.4 \\
(4.5-9.0)\end{array}$ & $\begin{array}{r}6.5 \pm 0.4 \\
(4.5-8.0)\end{array}$ & $\begin{array}{l}5.9 \pm 0.4 \\
(3.5-7.5)\end{array}$ & $\begin{array}{l}5.0 \pm 0.4 * \\
(2.0-7.0)\end{array}$ & $\begin{array}{r}6.2 \pm 0.2 \\
(4.5-7.0)\end{array}$ & $\begin{array}{c}9.1 \pm 0.8 \ddagger \\
(5.5-14.5)\end{array}$ \\
\hline$\%_{\mathrm{FT}}$ & $\begin{array}{l}0.026 \pm 0.001 \\
(0.021-0.032)\end{array}$ & $\begin{array}{l}0.025 \pm 0.001 \\
(0.020-0.032)\end{array}$ & $\begin{array}{l}0.029 \pm 0.002 \\
(0.021-0.038)\end{array}$ & $\begin{array}{l}0.035 \pm 0.004 \ddagger \\
(0.023-0.052)\end{array}$ & $\begin{array}{l}0.029 \pm 0.005 \\
(0.015-0.049)\end{array}$ & $\begin{array}{c}0.023 \pm 0.002 \\
(0.015-0.031)\end{array}$ \\
\hline $\mathrm{AFT}_{4}$ & $\begin{array}{r}1.8 \pm 0.2 \\
(1.1-2.4)\end{array}$ & $\begin{array}{r}1.6 \pm 0.1 \\
(1.1-2.6)\end{array}$ & $\begin{array}{l}1.7 \pm 0.1 \\
(1.0-2.1)\end{array}$ & $\begin{array}{l}1.7 \pm 0.1 \\
(1.2-2.6)\end{array}$ & $\begin{array}{l}1.8 \pm 0.2 \\
(1.1-2.6)\end{array}$ & $\begin{array}{l}2.1 \pm 0.2 \\
(1.3-3.4)\end{array}$ \\
\hline
\end{tabular}

Mean values $\pm \mathrm{SE}$ are shown with range of determinations for each time period in parentheses. Basal values are means of values obtained at 5 days and immediately prior to inoculation. 96-h and $192-\mathrm{h}$ values exclude those in the monkey that died at $51 \mathrm{~h}$. Abbreviations as in Table $\mathrm{I}$.

$* P<0.01$ compared with corresponding basal value.

$\ddagger P<0.05$ compared with corresponding basal value.

by an increase (peak, $127 \%$ at $72 \mathrm{~h}$ ) was also noted in SALM; since only three monkeys were studied, the PB ${ }^{205}$ I data in this group were not analyzed statistically, however.

Studies of the distributive disappearance of $T_{4}$. Table III summarizes the changes in distributive disappearance of $\left.{ }^{121} \mathrm{I}\right] \mathrm{T}$, in individual monkeys at 4, 14, 24, and $72 \mathrm{~h}$ after inoculation with heat-killed (SALM) or viable (INF) $S$. typhimurium and compares these with values in a group of concurrently studied monkeys inoculated with saline (CONT). $\mathrm{CU}_{\mathrm{T}_{\sharp}}$, expressed as a percent of the dose of $\left[{ }^{121} \mathrm{I}\right] \mathrm{T}_{4}$ outside the $\left[{ }^{125} \mathrm{I}\right] \mathrm{Alb}$ space at $60 \mathrm{~min}$ after injection, was increased in both SALM and INF at $4 \mathrm{~h}$ (range, 41.4-52.5) compared with values in six CONT (range, 17.0-30.3). Although only two SALM and two INF were studied at 14 and $24 \mathrm{~h}$, $\mathrm{CU}_{\mathrm{T}_{4}}$ was increased at these times in the latter (range, 32.4-40.5), but not the former (range, 19.3-26.9). By $72 \mathrm{~h}, \mathrm{CU}_{\mathrm{T}_{4}}$ in two INF (18.8 and 26.8) was within the range of CONT. Significant deiodination of $\left[{ }^{181} \mathrm{I}\right] \mathrm{T}$. in the $60 \mathrm{~min}$ period following its injection seemed unlikely, since in all monkeys studied urinary excretion and thyroidal uptake of ${ }^{121} \mathrm{I}$ were negligible (total, $<1.8 \%$ dose) and no increase in the percent of nonTCA precipitable ${ }^{28} \mathrm{I}$ in serum was noted. Values for
\%FT، postinoculation in SALM and INF did not differ significantly from those of CONT or their own basal values.

Table IV presents the values for hepatic and renal uptakes of $\left[{ }^{21} \mathrm{I}\right] \mathrm{T}$, and the calculated distribution spaces. Hepatic T uptake and space were increased in both SALM and INF at $4 \mathrm{~h}$ postinoculation compared with CONT. Thereafter, hepatic T uptake in these groups was similar to that of CONT. However, hepatic space in INF, calculated as the quotient of the net organ uptake of ${ }^{211} \mathrm{I}$ and the concentration of $\left[{ }^{212} \mathrm{I}\right] \mathrm{T}_{4}$ in the 60 min serum sample, was still increased (range, 29.2$43.0 \mathrm{ml}$ ) at 14 and $24 \mathrm{~h}$ relative to CONT (range, 14.631.6 ), owing to the lower concentration of $\left[{ }^{201} \mathrm{I}\right] \mathrm{T}_{4}$ in serum. Hepatic T \& uptake did not account for the increase in CU $\mathbb{T}_{4}$ in SALM or INF at any time interval examined. Consistent changes in renal $T_{\text {t }}$ uptake or space were not observed.

The accelerated early disappearance of $\left[{ }^{201} \mathrm{I}\right] \mathrm{T}$, from serum appeared to be due to the presence of bacteria in the inoculum, for it was observed with washed bacteria but not with the supernate of the original inoculum or with endotoxin derived from $S$. typhimurium. As depicted in Fig. 3, accelerated disappearance of $\left[{ }^{2 x 1} \mathrm{I}\right] \mathrm{T}$. also occurred during the first $8 \mathrm{~h}$ after i.v. inoculation 
TABLE III

Sequential Changes in the Distributive Disappearance of L-Thyroxine $\left(T_{4}\right)$ in Rhesus Monkeys Inoculated with Salmonella typhimurium

\begin{tabular}{|c|c|c|c|c|c|c|}
\hline \multirow{3}{*}{$\begin{array}{c}\text { Monkey } \\
\text { group }\end{array}$} & \multirow{3}{*}{$\begin{array}{c}\text { Monkey } \\
\text { no. }\end{array}$} & \multirow{2}{*}{\multicolumn{3}{|c|}{ Cellular Uptake of $\left[{ }^{131} \mathrm{I}\right] \mathrm{T}_{4}$}} & \multicolumn{2}{|c|}{$\% \mathrm{FT}_{4} *$} \\
\hline & & & & & \multirow[b]{2}{*}{ Basal } & \multirow{2}{*}{$\begin{array}{l}\text { Post- } \\
\text { inocula- } \\
\text { tion }\end{array}$} \\
\hline & & $10 \mathrm{~min} \ddagger$ & $30 \mathrm{~min} \ddagger$ & $60 \min \ddagger$ & & \\
\hline \multicolumn{7}{|c|}{$\%$ dose } \\
\hline \multirow[t]{6}{*}{ CONT } & 1 & 17.5 & 22.1 & 25.6 & 0.024 & 0.025 \\
\hline & 2 & 22.8 & 25.2 & 27.9 & 0.026 & 0.026 \\
\hline & 3 & 12.5 & 19.2 & 22.3 & 0.023 & 0.027 \\
\hline & 4 & 16.3 & 20.7 & 23.8 & 0.033 & 0.036 \\
\hline & 5 & 9.1 & 12.5 & 17.0 & 0.028 & 0.025 \\
\hline & 6 & 21.3 & 25.8 & 30.3 & 0.029 & 0.030 \\
\hline \multirow{3}{*}{\multicolumn{2}{|c|}{$\begin{array}{l}\text { Mean } \\
\mathrm{SD} \\
4 \mathrm{~h} \text { postinoculation }\end{array}$}} & 16.6 & 20.9 & 24.5 & 0.027 & 0.028 \\
\hline & & 5.2 & 4.8 & 4.6 & 0.004 & 0.004 \\
\hline & & & & & & \\
\hline \multirow[t]{2}{*}{ SALM } & 7 & 31.9 & 45.2 & 52.5 & 0.027 & 0.024 \\
\hline & 8 & 30.8 & 39.0 & 45.0 & 0.030 & 0.031 \\
\hline \multirow[t]{3}{*}{ INF } & 9 & 31.7 & 38.9 & 46.2 & 0.029 & 0.027 \\
\hline & 10 & 32.6 & 42.6 & 52.0 & 0.025 & 0.022 \\
\hline & 11 & 32.1 & 36.7 & 41.4 & 0.031 & 0.032 \\
\hline \multicolumn{7}{|c|}{$14 \mathrm{~h}$ postinoculation } \\
\hline \multirow[t]{2}{*}{ SALM } & 12 & 14.3 & 19.0 & 24.1 & 0.032 & 0.030 \\
\hline & 13 & 11.6 & 15.1 & 19.3 & 0.026 & 0.029 \\
\hline \multirow[t]{2}{*}{ INF } & 14 & 25.2 & 30.1 & 36.7 & 0.024 & 0.026 \\
\hline & 15 & 20.5 & 25.6 & 32.4 & 0.029 & 0.029 \\
\hline \multicolumn{7}{|c|}{$24 \mathrm{~h}$ postinoculation } \\
\hline \multirow[t]{2}{*}{ SALM } & 16 & 13.7 & 18.0 & 23.2 & 0.026 & 0.028 \\
\hline & 17 & 17.0 & 22.4 & 26.9 & 0.033 & 0.031 \\
\hline \multirow[t]{2}{*}{ INF } & 18 & 25.7 & 34.1 & 40.5 & 0.028 & 0.029 \\
\hline & 19 & 21.3 & 29.6 & 35.1 & 0.027 & 0.032 \\
\hline \multicolumn{7}{|c|}{$72 \mathrm{~h}$ postinoculation } \\
\hline \multirow[t]{2}{*}{ INF } & 20 & 9.7 & 15.2 & 18.8 & 0.026 & 0.029 \\
\hline & 21 & 16.0 & 22.9 & 26.8 & 0.029 & 0.035 \\
\hline
\end{tabular}

Abbreviations as in Table I.

* Basal \% $\mathrm{FT}_{4}$ represents value obtained immediately prior to i.v. inoculation with saline or bacteria, and postinoculation values represent those obtained at times indicated.

$\ddagger$ Refers to time after simultaneous i.v. injection of [131I] $\mathrm{T}_{4}$ and [125I]Alb.

with heat-killed or viable $E$. coli or viable pneumococci, $P<0.01$, compared with saline controls. In the monkeys inoculated with the viable organisms, $K_{\mathbf{T}_{4}}$ was accelerated during the $48 \mathrm{~h}$ period of acute septic illness compared with the saline controls, $P<0.01$.

\section{DISCUSSION}

Our data indicate that in the rhesus monkey increased cellular uptake and metabolism of $T_{4}$ occur during $S$. typhimurium bacteremia and suggest that accelerated metabolism also occurs during $E$. coli bacteremia. These alterations are reminiscent of those that we have previously reported during pneumococcal infection in this species $(2,3)$.

In the monkeys inoculated with either heat-killed (SALM) or viable (INF) $S$. typhimurium, an in- creased rate of disappearance of $\left.{ }^{[131} \mathrm{I}\right] \mathrm{T}$, from serum was evident during the first $8 \mathrm{~h}$ postinoculation. This increase reflected not only accelerated distributive disappearance, but accelerated metabolic disappearance as well, since increases in both thyroidal uptake of ${ }^{182} \mathrm{I}$ and the percent of non-TCA precipitable ${ }^{181} \mathrm{I}$ in serum were observed. This accelerated metabolism of $T_{4}$ occurring prior to attainment of distribution equilibrium resulted in an exaggerated increase in the calculated values for $\mathrm{V}_{\mathrm{T}_{\mathbf{4}} \text {. }}$

In SALM, the alterations in $\mathrm{T}_{4}$ kinetics were transient. By $16 \mathrm{~h}$ after inoculation with the organisms, the rate of disappearance of $\left.{ }^{131} \mathrm{I}\right] \mathrm{T}_{4}$ from serum was no longer increased, and the increase in $\mathrm{CU}_{\mathrm{T}_{*}}$ that was evident at $4 \mathrm{~h}$ after inoculation with the bacteria had disappeared by $14 \mathrm{~h}$. By contrast, in INF, the acceleration of $T_{4}$ disappearance persisted in most instances for the duration of the septic illness. This was especially

TABLE IV

Sequential Changes in Hepatic and Renal Uptakes and Distribution Spaces of L-thyroxine $\left(T_{4}\right)$ in Rhesus Monkeys Inoculated with Salmonella typhimurium

\begin{tabular}{|c|c|c|c|c|c|c|c|}
\hline \multirow{2}{*}{$\begin{array}{c}\text { Monkey } \\
\text { group }\end{array}$} & \multirow{2}{*}{$\begin{array}{c}\text { Monkey } \\
\text { no. }\end{array}$} & \multicolumn{3}{|c|}{ Hepatic } & \multicolumn{3}{|c|}{ Renal } \\
\hline & & Uptake & Uptake & Space & Uptake & Uptake & Space \\
\hline \multirow{7}{*}{ CONT } & & $\begin{array}{l}\% \text { dose } \\
{\left[{ }^{131} I\right] T}\end{array}$ & $\% C U_{T_{4}}$ & $m l$ & $\begin{array}{c}\% \text { dose } \\
{\left[{ }^{121} I\right] T_{4}}\end{array}$ & $\% C U_{T_{4}}$ & $m l$ \\
\hline & 1 & 17.5 & 68.4 & 31.6 & 3.0 & 11.7 & 5.4 \\
\hline & 2 & 16.2 & 58.1 & 30.3 & 4.6 & 16.5 & 8.1 \\
\hline & 3 & 10.1 & 45.3 & 17.8 & 3.2 & 14.3 & 5.7 \\
\hline & 4 & 13.5 & 56.7 & 24.5 & 1.8 & 7.6 & 3.3 \\
\hline & 5 & 9.8 & 57.6 & 14.6 & 2.7 & 15.9 & 4.0 \\
\hline & 6 & 17.9 & 59.7 & 30.1 & 3.6 & 11.9 & 7.4 \\
\hline Mean & & 14.2 & 57.6 & 24.8 & 3.2 & 12.9 & 5.7 \\
\hline $\mathrm{SD}$ & & 3.7 & 7.4 & 7.2 & 0.9 & 3.3 & 1.9 \\
\hline \multicolumn{8}{|c|}{$4 \mathrm{~h}$ postinoculation } \\
\hline \multirow[t]{2}{*}{ SALM } & 7 & 24.9 & 47.4 & 55.5 & 2.1 & 4.0 & 6.4 \\
\hline & 8 & 23.6 & 52.4 & 75.6 & 2.9 & 6.4 & 6.8 \\
\hline \multirow[t]{3}{*}{ INF } & 9 & 25.4 & 55.0 & 78.3 & 3.4 & 7.4 & 10.5 \\
\hline & 10 & 26.1 & 50.2 & 69.6 & 2.2 & 4.2 & 5.9 \\
\hline & 11 & 19.5 & 47.1 & 42.6 & 3.3 & 8.0 & 7.2 \\
\hline \multicolumn{8}{|c|}{$14 \mathrm{~h}$ postinoculation } \\
\hline \multirow[t]{2}{*}{ SALM } & 12 & 14.9 & 61.8 & 27.9 & 4.1 & 17.0 & 8.9 \\
\hline & 13 & 10.7 & 55.4 & 18.0 & 2.8 & 14.5 & 4.7 \\
\hline \multirow[t]{2}{*}{ INF } & 14 & 16.5 & 44.9 & 39.5 & 3.1 & 8.4 & 7.4 \\
\hline & 15 & 14.7 & 45.4 & 29.2 & 3.0 & 9.2 & 6.0 \\
\hline \multicolumn{8}{|c|}{$24 \mathrm{~h}$ postinoculation } \\
\hline \multirow[t]{2}{*}{ SALM } & 16 & 14.0 & 60.3 & 26.6 & 4.0 & 17.2 & 7.6 \\
\hline & 17 & 13.7 & 50.9 & 24.9 & 3.5 & 13.0 & 6.3 \\
\hline \multirow[t]{2}{*}{ INF } & 18 & 16.5 & 40.7 & 43.0 & 2.8 & 6.9 & 6.6 \\
\hline & 19 & 18.0 & 51.3 & 37.8 & 3.7 & 10.5 & 7.8 \\
\hline \multicolumn{8}{|c|}{$72 \mathrm{~h}$ postinoculation } \\
\hline \multirow[t]{2}{*}{ INF } & 20 & 10.7 & 56.9 & 18.2 & 2.5 & 13.3 & 4.3 \\
\hline & 21 & 14.0 & 52.2 & 25.0 & 4.3 & 16.0 & 7.7 \\
\hline
\end{tabular}

Hepatic and renal uptakes and spaces were determined $60 \mathrm{~min}$ after simultaneous i.v. injection of $\left.{ }^{131} \mathrm{I}\right] \mathrm{T}$ and $\left[{ }^{125} \mathrm{I}\right] \mathrm{Alb}$ at the times indicated. $\mathrm{CU}_{\mathrm{T}}$, cellular uptake of $\left.{ }^{[131} \mathrm{I}\right] \mathrm{T}_{4}$. Abbreviations as in Table I. 
well demonstrated in monkey 22 whose prolonged septic illness was associated with a correspondingly prolonged

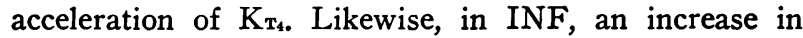
$\mathrm{CU}_{\mathrm{N}_{*}}$ was evident for up to $24 \mathrm{~h}$ postinoculation.

In the present study, we sought to define the pathogenetic factor(s) underlying the increased cellular uptake and metabolism of $T_{4}$ in SALM and INF. Several possible factors would appear to be excluded by our findings. First, fever did not appear to play a role since it did not occur in SALM. Second, a generalized increase in vascular permeability permitting escape from the vascular compartment of $T_{4}$ in association with its binding proteins could not be implicated, since the rate of disappearance of $\left.{ }^{[125} \mathrm{I}\right] \mathrm{Alb}$ from serum was not increased relative to that in the control animals. Third, a decrease in the binding of hormone in plasma would appear to be discounted by the observation that the alterations in $T$, kinetics preceded a detectable increase in $\% \mathrm{FT}$, in serum. Finally, since the gastrointestinal tract is a major locus of Salmonella infection, increased fecal clearance of hormone could have been a factor, and indeed diarrhea occurred in 2 of 11 INF; however, similar alterations in $T_{4}$ kinetics have been shown to occur during acute pneumococcal infection $(2,3)$, an illness in which diarrhea is not a feature. Rather, our findings are more consistent with a primary increase in the cellular uptake and metabolism of $\mathrm{T}$, during bacterial sepsis.

In addition to acute bacterial infection, accelerated disappearance of $T$, has been observed to occur during several other hypermetabolic states including muscular exercise (19), cold exposure (20), acute adaptation to high altitude (21), leukemia (12), active acromegaly (22), treated Graves' disease (23), and salicylate administration $(24,25)$. In many of these circumstances (19, 21-23), as during acute bacterial sepsis, the acceleration of $T_{4}$ disappearance could not be ascribed to a decrease in the binding of hormone in plasma, suggesting that cellular metabolism was primarily increased. The mechanisms underlying the latter remain uncertain and could vary widely in the various circumstances.

The effects of Salmonella on $\mathrm{T}_{4}$ kinetics appeared to be owing to the presence of the bacteria themselves. First, an increase in the rate of disappearance of [191 I]T from serum followed inoculation with washed Salmonella, but did not occur following inoculation with the supernate of the usual inoculum of unwashed organisms, excluding a role for an in vitro product of bacterial growth. Second, inoculation with up to 1500 $\mu \mathrm{g}$ of $S$. typhimurium endotoxin, an amount many fold in excess of that present in $10^{\circ}$ Salmonella, was not accompanied by an increase in the rate of disappearance of $\left.{ }^{[13} \mathrm{I}\right] \mathrm{T}_{4}$ from serum. However, this lack of response may merely have meant that the batch of endotoxin em-

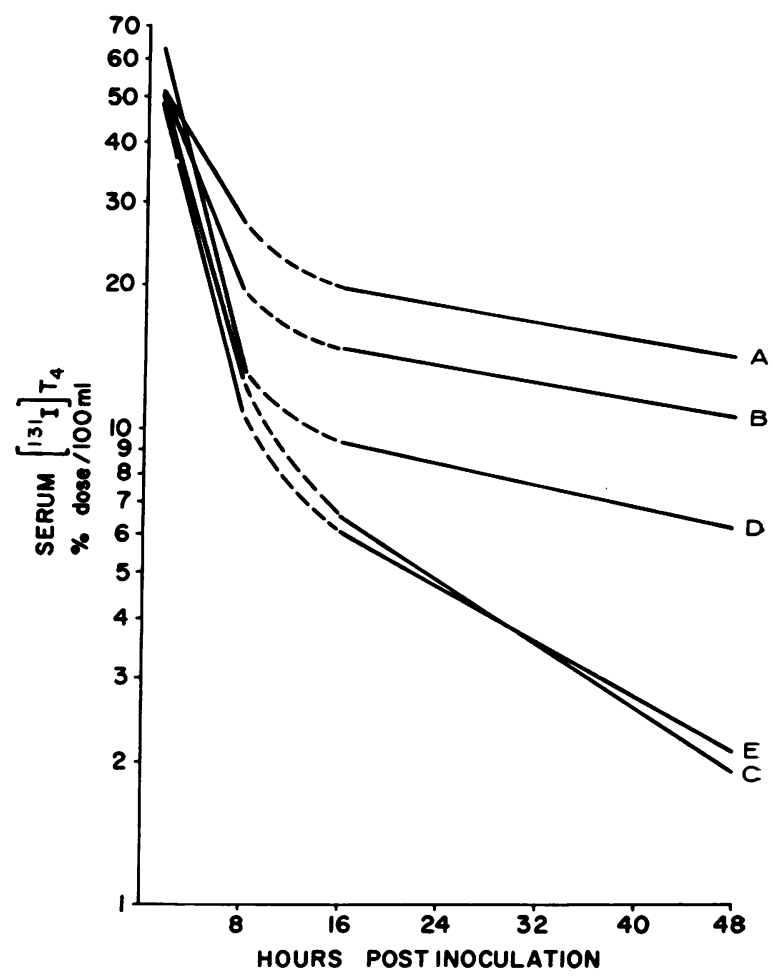

FIgURE 3 Mean best-fit regression curves for the disappearance from serum of ${ }^{131} \mathrm{I}$-labeled L-thyroxine ( $\left[{ }^{131} \mathrm{I}\right] \mathrm{T}_{4}$ ) during a $48 \mathrm{~h}$ period following i.v. inoculation of : $\mathrm{A}$, six rhesus monkeys with saline; $B$, three with $10^{\circ}$ heat-killed $D$. pneumoniae; $\mathrm{C}$, three with $10^{\circ}$ viable $D$. pneumoniae; D, three with $10^{\circ}$ heat-killed $E$. coli; and $\mathrm{E}$, three with $10^{\circ}$ viable $E$. coli. Blood cultures of monkeys receiving viable pneumococci or $E$. coli grew these organisms at 24 and $48 \mathrm{~h}$.

ployed was inactive. In any event, accelerated $T_{4}$ disappearance was also observed following inoculation with viable $D$. pneumoniae, an organism from which an endotoxin is not derived. Hence, if it is granted that the bacteria themselves were a prerequisite for the alterations observed, the increased cellular uptake and metabolism of $T$, may have been related to phagocytic cell function in the host. Indeed, peripheral blood leukocytes have been shown to actively take up and deiodinate $T$. in vitro $(26,27)$, and recent work has demonstrated that $T$, deiodination is enhanced when phagocytosis is induced $(8,9)$. Moreover, leukocytes isolated from the blood of rhesus monkeys previously inoculated with viable $D$. pneumoniae display an increase in $\mathrm{T}_{4}$-deiodinating activity (2). Finally, the accelerated disappearance of $T$, that was observed by Sterling and Chodos (12) in four patients with leukemia could have resided. at least in part, in the increased mass of circulating leukocytes. In the case of bacterial sepsis, increased deiodinating activity in phagocytosing cells might con- 
stitute a host defence mechanism in which the iodine generated from thyroid hormone is utilized for the iodination and killing of ingested bacteria $(5,8,9)$.

An absolute neutrophilia occurred in the monkeys inoculated with heat-killed or viable Salmonella, and this phenomenon appeared to correspond in duration with the acceleration of $T_{\text {s }}$ disappearance. However, its contribution to the acceleration of hormonal disappearance remains to be defined, since fixed phagocytic cells of the reticuloendothelial system, such as hepatic Kupffer cells and cells in the splenic sinuses, rather than circulating leukocytes, appear to play the preponderant role in the clearance of organisms administered as an i.v. bolus (28), as was the case here. Although data bearing on this point are lacking, it seems likely that fixed phagocytic cells are also able to deiodinate $T_{4}$ in view of the evidence that $T$, deiodination may be mediated by a peroxidase-hydrogen peroxide system (29) and that phagocytic cells other than circulating leukocytes, such as peritoneal and alveolar macrophages, also generate increased quantities of hydrogen peroxide during phagocytosis $(30,31)$. Moreover, the increased hepatic uptake of $T_{4}$ observed in the bacteremic monkeys may have been related to altered Kupffer cell activity in view of the evidence that Kupffer cells may possess a peroxidase-mediated antimicrobial system similar to that found in circulating leukocytes (32). Thus, the foregoing considerations would assign to phagocytic cells a primary role in the genesis of the increased cellular uptake and metabolism of $T_{4}$ in bacterial sepsis.

The sequential alterations in serum total $T$, and PB ${ }^{195}$ I concentrations that were observed in the infected monkeys also deserve comment. The initial decline in serum total $T_{4}$ and $P B{ }^{125} \mathrm{I}$ and the subsequent increase strongly suggest that an increase in thyroidal secretion of hormone occurred in response to depletion of the peripheral hormonal pool. In addition, the late increase in serum total $T$, and $P B{ }^{185} \mathrm{I}$ to values in excess of preinoculation values suggest that a "physiologic overshoot" occurred as homeostatsis was restored. This biphasic phenomenon has been noted during other acute infections $(14,15)$, and may serve to explain some conflicting reports concerning alterations in serum thyroid hormone concentration during infection (16). Finally, in the light of the above observations, an inability to compensate for the progressive depletion of the peripheral pool of hormone during a septic illness might account for the reported aggravation of hypothyroidism in this circumstance (33).

\section{ACKNOWLEDGMENTS}

In conducting the research described in this report, the investigators adhered to the "Guide for Laboratory Animal Facilities and Care", as promulgated by the Committee on the Guide for Laboratory Animal Facilities and Care of the Institute of Laboratory Animal Resources, National Academy of Sciences-National Research Council. The facilities are fully accredited by the American Association of Accreditation of Laboratory Animal Care.

The authors are indebted to Specialists Fred H. Kuykendall, Stephen D. Ervin, and William E. Nesbit and to Mr. Wallace Fee for expert technical assistance, to Mrs. Phebe Summers for assistance in preparation of the figures, and to Mrs. Ann Clabaugh, Mrs. Phylis Rinehart, Mrs. Mary Culler, and Mrs. Edith Cusher for secretarial help.

\section{REFERENCES}

1. Gregerman, R. I., and N. Solomon. 1967. Acceleration of thyroxine and triiodothyronine turnover during bacterial pulmonary infections and fever: implications for the functional state of the thyroid during stress and in senescence. J. Clin. Endocrinol. Metab. 27: 93.

2. Woeber, K. A. 1971. Alterations in thyroid hormone economy during acute infection with Diplococcus pneumoniae in the rhesus monkey. J. Clin. Invest. 50: 378.

3. DeRubertis, F. R., and K. A. Woeber. 1972. Evidence for enhanced cellular uptake and binding of thyroxine in vivo during acute infection with Diplococcus preumoniae. J. Clin. Invest. 51 : 788.

4. Adelberg, H. M., J. K. Siemsen, R. C. Jung, and J. T. Nicoloff. 1971. Scintigraphic detection of pulmonary bacterial infections with labeled thyroid hormones and pertechnetate. Radiology. 99 : 141.

5. Klebanoff, S. J. 1967. Iodination of bacteria : a bactericidal mechanism. J. Exp. Med. 126: 1063.

6. Klebanoff, S. J. 1968. Myeloperoxidase-halide-hydrogen peroxide antibacterial system. J. Bacteriol. 95: 2131 .

7. Pincus, S. H., and S. J. Klebanoff. 1971. Quantitative leukocyte iodination. $N$. Engl. J. Med. 284: 744.

8. Woeber, K. A., G. F. Doherty, and S. H. Ingbar. 1972. Stimulation by phagocytosis of the deiodination of Lthyroxine in human leukocytes. Science (Wash. D. C.). $176: 1039$.

9. Klebanoff, S. J., and W. L. Green. 1972. Metabolism of thyroid hormones by phagocytizing human leukocytes. J. Clin. Invest. 51 : 51a. (Abstr.)

10. Paul, B. B., A. A. Jacobs, R. R. Strauss, and A. J. Sbarra. 1970. Role of the phagocyte in host-parasite interactions. XXIV. Aldehyde generation by the myeloperoxidase- $\mathrm{H}_{2} \mathrm{O}_{2}$-chloride antimicrobial system: a possible in vivo mechanism of action. Infect. Immun. 2: 414.

11. Jacobs, A. A., G. W. Mitchell, Jr., R. R. Strauss, B. B. Paul, and A. J. Sbarra. 1971. The role of the phagocyte in host-parasite interactions. XXXI. Serum and cellular iodine levels and their relationship to the hyperbactericidal activity of pregnancy. Am. J. Obstet. Gynecol. 110: 911.

12. Sterling, K, and R. B. Chodos. 1956. Radiothyroxine turnover studies in myxedema, thyrotoxicosis, and hypermetabolism without endocrine disease. J. Clin. Invest. $35: 806$.

13. Wiswell, J. G., and V. Coronho. 1962. Disappearance of $I^{121}$-triiodothyronine from the plasma in the presence of fever. J. Clin. Endocrinol. Metab. 22: 657.

14. Lutz, J. H., R. B. Hornick, A. T. Dawkins, Jr., and R. I. Gregerman. 1967. Independence of changes of thyroxine ( $T_{4}$ ) binding proteins, free $T_{4}$ and $T_{4}$ turnover during experimental infections in man. Program of American Thyroid Association. 53. (Abstr.) 
15. Shambaugh, G. E. III, and W. R. Beisel. 1967. Early alterations in thyroid hormone physiology during acute infection in man. J. Clin. Endocrinol. Metab. 27: 1667.

16. Beck, G. E., J. Pasquier, and Th. Béraud. 1956. La fonction thyroidienne dans les états febriles. Schweiz. Med. Wochenschr. 86: 1300.

17. Snedecor, G. W., and W. G. Cochran. 1967. Statistical Methods. The Iowa State University Press, Ames. 6th edition.

18. Oppenheimer, J. H., G. Bernstein, and J. Hasen. 1967. Estimation of rapidly exchangeable cellular thyroxine from the plasma disappearance curves of simultaneously administered thyroxine- ${ }^{28 I} \mathrm{I}$ and albumin- ${ }^{125} \mathrm{I}$. J. Clin. Invest. 46: 762 .

19. Irvine, C. H. G. 1968. Effect of exercise on thyroxine degradation in athletes and non-athletes. J. Clin. Endocrinol. Metab. $28: 942$.

20. Freinkel, N., and D. Lewis. 1957. The effect of lowered environmental temperature on the peripheral metabolism of labelled thyroxine in the sheep. J. Physiol. 135: 288.

21. Surks, M. I., H. J. Beckwitt, and C. A. Chidsey. 1967. Changes in plasma thyroxine concentration and metabolism, catecholamine excretion and basal oxygen consumption in man during acute exposure to high altitude. J. Clin. Endocrinol. Metab. $27: 789$.

22. Inada, M., and K. Sterling. 1967. Thyroxine turnover and transport in active acromegaly. J. Clin. Endocrinol. Metab. 27: 1019.

23. Ingbar, S. H., and N. Freinkel. 1958. Studies of thyroid function and the peripheral metabolism of $\mathrm{I}^{180}$-labeled thyroxine in patients with treated Graves' disease. $J$. Clin. Invest. 37: 1603 .
24. Austen, F. K., M. E. Rubini, W. H. Meroney, and J. Wolff. 1958. Salicylates and thyroid function. I. Depression of thyroid function. J. Clin. Invest. 37: 1131.

25. Woeber, K. A., and S. H. Ingbar. 1964. The effects of noncalorigenic congeners of salicylate on the peripheral metabolism of thyroxine. J. Clin. Invest. 43: 931.

26. Siegel, E., and B. A. Sachs. 1964. In vitro leukocyte uptake of Isi-labeled iodide, thyroxine and triiodothyronine, and its relation to thyroid function. J. Clin. Endocrinol. Metab. 24 : 313.

27. Kurland, G. S., M. V. Krotkov, and A. S. Freedberg. 1960. Oxygen consumption and thyroxine deiodination by human leukocytes. J. Clin. Endocrinol. Metab. 20: 35 .

28. Rogers, D. E. 1960. Host mechanisms which act to remove bacteria from the blood stream. Bacteriol. Rev. $24: 50$.

29. Galton, V. A., and S. H. Ingbar. 1963. Role of peroxidase and catalase in the physiological deiodination of thyroxine. Endocrinol. 73: 596.

30. Paul, B. B., R. R. Straus, A. A. Jacobs, and A. J. Sbarra. 1970. Function of $\mathrm{H}_{2} \mathrm{O}_{2}$, myeloperoxidase, and hexose monophosphate shunt enzymes in phagocytizing cells from different species. Infect. Immun. 1: 338 .

31. Gee, J. B. L., C. L. Vassallo, P. Bell, J. Kaskin, R. E. Basford, and J. B. Field. 1970. Catalase-dependent peroxidative metabolism in the alveolar macrophage during phagocytosis. J. Clin. Invest. 49: 1280.

32. Fahimi, H. D. 1970. The fine structural localization of endogenous and exogenous peroxidase activity in Kupffer cells of rat liver. J. Cell. Biol. 47: 247.

33. Hausmann, W., and A. J. Karlish. 1961. Acute myxoedema precipitated by pneumonia. Report of five cases. Br. Med.J. 2: 1063. 